\title{
Питання психології
}

Фурс О. Й., заступник начальника факультету по роботі з особовим складом, Воєнно-дипломатичної академії

\section{РЕЗУЛЬТАТИ \\ ВПЛИВУ ЗДАТНОСТІ ДО САМОРЕГУЛЯЩЇ МАЙБУТНІХ ФАХІВЦІВ ЕКСТРЕМАЛЬНИХ ВИДІВ ДІЯЛЬНОСТІ НА УСПІШНІСТЬ ЇХ ФАХОВОЇ ПІДГОТОВКИ}

\begin{abstract}
У статті визначено одну з провідних психологічних проблем - здатність до саморегуляції фахівціів екстремальних видів діяльності. Обтрунтовано необхідність у проведенні ї̈ експериментальної перевірки у військовослужбовців, які виконують завдання в зоні бойових дій. Розглянуто наукові погляди науковців щуодо розуміння здатності представників спеціальних підрозділів до управління власними психічними станами в екстремальних ситуачіях. Апробовано методики діагностування здатності до психічної саморегуляції офіцерів оперативно-тактичного рівня підготовки.

Ключові слова: здатність до саморегулящї, фахівці екстремальних видів діяльності, успішність, фахова підготовка, кореляційний аналіз, статистичний зв'язок.

В статье определена одна из ведущих психологических проблем - способность к саморегулящии специалистов экстремальньх видов деятельности. Обоснована необходимость в проведении ее экспериментальной проверки у военнослужащих, которые выполняют задания в зоне боевых действий. Рассмотрень научные подходы учёных относительно понимания способности представителей специальных подразделений к управлению собственными психическими состояниями в экстремальньх ситуациях. Апробировань методики, для диагностирования влияния способности к саморегуляции офицеров оперативно-тактического уровня подготовки. Ключевые слова: способность к саморегуляции, специалисть экстремальных видов деятельности, успеваемость, специальная подготовка, корреляционный анализ, статистическая связь.
\end{abstract}

Постановка проблеми. У пункті 1.3. Положення про Психологічну службу Збройних Сил України зазначається, що "Психологічне забезпечення $є$ складовою морально-психологічного забезпечення i являє собою систему узгоджених, цілеспрямованих заходів, які грунтуються на досягненнях сучасної психологічної науки i проводяться в інтересах підготовки та застосування військ (сил), формування, підтримання та відновлення психологічної стійкості, психологічної готовності особового складу, збереження психічного здоров'я військовослужбовців, членів їх сімей, цивільного персоналу, резервістів Збройних Сил України““ [4, с.1].

Стан ситуації на Сході України показує, що захистити незалежність і територіальну цілісність держави можуть лише морально та психологічно стійкі військовослужбовці, які за будь-яких умов бойової обстановки готові до виконання поставлених завдань. Відповідно, одним із напрямків психологічної підготовки в таких умовах $\epsilon$ вдосконалення та покращення методики формування та розвитку емоційно-вольової стійкості особового складу. Адже, як показуе бойовий досвід, тривала психологічна напруженість, екстремальні ситуації в зоні антитерористичної операції (ATO) виокремили одну 3 гострих психологічних проблем - здатність до саморегуляції фахівців екстремальних видів діяльності.

Підвищені вимоги до них в період виконання спеціальних завдань і в зоні АТО зумовили необхідність у проведенні експериментальної перевірки щодо з'ясування їх здатності до саморегуляції та іiі впливу на успішність фахової підготовки на прикладі майбутніх магістрів військового управління в міжнародних відносинах (МВУМВ).

Аналіз останніх досліджень. Серед актуальних проблем сучасної психології $€$ проблема формування та розвитку здатності фахівців екстремальних видів діяльності не лише до управління особовим складом, але й власними психічними станами. Під здатністю фахівців спеціальних підрозділів до управління власним психічним станом ми розуміємо одну 3 його спеціальних інтегральних здатностей, яка вкрай необхідна для виконання професійних функцій в екстремальних умовах.

Це відзначає також С.Д. Максименко, який наголошує про те, що "Регуляція $\mathrm{i}$ саморегуляція психічних станів фахівця спеціального підрозділу відноситься до числа його провідних професійних здібностей, які дозволяють йому в самих складних умовах бути зразком для цілеспрямованого наслідування іншими співробітниками" $[3, \quad$ с.188]. Професія 


\section{Питання психології}

фахівця спеціального підрозділу пов'язана 3 життєдіяльністю в особливих, більш екстремальних, порівняно 3 іншими сферами, умовами існування людства. Вплив екстремальних чинників може бути короткочасним і довготривалим. У першому випадку актуалізуються, на думку науковців, програми реагування, які завжди "напоготові" в особи, у другому вимагається адаптаційна перебудова функціональних систем людини, іноді вкрай неприємна для неї, а іноді - навіть несприятлива для іiї здоров'я [2, с. 138].

За визначенням В.Д. Небиліцина, екстремальні подразники представляють собою крайні (межові) значення тих елементів ситуації, які створюють оптимальний фон для діяльності або у всякому разі не виключають відчуття дискомфорту [5, с.113].

Стрес i, відповідно, необхідність у саморегуляції психічної стійкості може виникати у тих випадках, коли зовнішня ситуація сприймається особою як висунення вимоги, що загрожує перевищити іiі здатності і ресурси. При цьому він має очікувати більших відмінностей між затратами на задоволення вимог i наслідками його задоволення або не задоволення [1, с.252]. Зазначене показує актуальність і важливість пошуку засобів розвитку здатності до саморегуляції у майбутніх фахівців екстремальних видів діяльності.

Ïх психічна стійкість займає одне 3 центральних місць в акмеологічних дослідженнях, в яких вона розглядається як здатність відповідати вимогам підтримання ефективності діяльності в різних, в тому числі й екстремальних ситуаціях. Як відмічає В.Р. Малкін, сутність психічної стійкості фахівця екстремальних видів діяльності являє собою специфічну особистісно-професійну орієнтацію, спрямовану на певні цілі, тобто, - це психічна стійкість, яка має відносно константний, але конкретний прояв усіх компонентів його психіки, які мають певну спрямованість і виражають гармонійність зв'язку 3 зовнішнім середовищем у конкретних умовах [6, с.17].

Проблемі психічної саморегуляції у вітчизняній психології приділяли увагу А. Якимчук, А. Порицький, Г. Грибенюк. I. Ковальова, О. Іванова та ін., які досліджують проблему професійної діяльності фахівців в особливих умовах. Але, аналіз літературних джерел показує, що нині потрібно експериментально перевірити вплив саморегуляції на успішність психологічної підготовки фахівця для того, щоб покращити його фахову підготовку та удосконалити навчально-виховний процес у ВВНЗ.

Крім того, зазначена проблема ускладнена відсутністю системних психологічних досліджень щодо впливу здатності до саморегуляції слухачів оперативно-тактичного рівня на їх успішність фахової діяльності. Хоча, певна кількість наукових робіт присвячена зазначеній темі i досліджувалася представниками інших силових структур держави.

У зв'язку з цим, приведений аналіз впливу здатності до саморегуляції фахівців екстремальних видів діяльності на успішність їх фахової підготовки надасть можливість отримати необхідний емпіричний матеріал, який сприятиме розумінню iї психологічної сутності та структури.

Крім того, результати викладені в статті зроблять певний внесок у дослідження діяльності військових фахівців в особливих умовах.

Таким чином, сполучення високого теоретичного та практичного значення 3 недостатньою розробленістю багатьох аспектів проблеми статті зумовило актуальність викладення та обгрунтування результатів експерименту.

Метою статті $\epsilon$ аналіз отриманих результатів - вплив здатності до саморегуляції майбутніх фахівців екстремальних видів діяльності на успішність їх фахової підготовки.

Виклад основного матеріалу. Проведений у рамках дослідження аналіз діяльності фахівців спеціальних підрозділів засвідчив, що вона суттєво ускладнилася. Основні показники цього стану - це проведення АТО на Сході України, яка викликана необхідністю виконувати службові обов'язки в екстремальних умовах.

Умови діяльності, що протікають під впливом екстремальних чинників, можна кваліфікувати у таких варіантах [7, с.181]:

Особливі умови діяльності, які пов'язані 3 епізодичним, непостійним 


\section{Питання психології}

впливом екстремальних чинників або високою усвідомлюваною можливістю їх появи у військовослужбовців які виконують завдання в зоні АТО. При цьому екстремальні чинники не мають великої сили або інтенсивності, а негативні функціональні стани, що виникають, виражені помірно. В таких умовах у військовослужбовців мобілізуються резервні можливості компенсаторного типу; після роботи в таких умовах їм необхідний відпочинок.

Екстремальні умови діяльності, які характеризуються постійним впливом інтенсивних екстремальних чинників, що можуть представляти потенційну небезпеку для фахівців спеціальних підрозділів. При цьому негативні функціональні стани особового складу в зоні АТО виражені сильніше, діяльність здійснюється 3 підключенням резервних буферних можливостей організму та психіки. Робота фахівців спеціальних підрозділів в таких умовах потребує відновлення (самостійного повернення до нормального психічного стану).

Надекстремальні умови діяльності характеризуються постійним впливом екстремальних чинників на військовослужбовців в зоні бойових дій, що мають високу інтенсивність і несуть реальну небезпеку. Функціональні стани, що виникають у них, мають крайній ступінь виразності, використовуються аварійні резервні можливості такої діяльності; після неї необхідна обов'язкова реабілітація військовослужбовців (повернення, корегування або компенсування порушених психічних функцій військовослужбовців, станів за допомогою спеціальних заходів).

У зв'язку 3 вищевикладеним постає необхідність дослідження проблеми впливу здатності до саморегуляції майбутніх фахівців екстремальних видів діяльності на успішність їх фахової підготовки, яка зумовлена підвищеною увагою до оптимізації їх навчальної діяльності та їх подальшої діяльності в складних умовах.

Наше дослідження складалося 3 двох етапів. На першому етапі була розроблена анкета, яка складається із запитань, що охоплюють різні психічні ускладнення та 3 якими стикалися майбутні МВУМВ.

Під час анкетного опитування з'ясували, що офіцери усвідомлюють необхідність розвитку здатностей до психічної саморегуляції. Так, на запитання анкети 'Чи необхідно навчитися методикам саморегуляції психічних станів" $98 \%$ респондентів дали позитивну відповідь i вказали, що вона є надзвичайно важливим елементом у фаховій діяльності співробітників спеціальних підрозділів (табл. 1).

Таблиия 1

Результати анкетного опитування слухачів, що відображають психічні ускладнення під час їх практичної підготовки

\begin{tabular}{|c|c|c|}
\hline $\begin{array}{l}\text { № } \\
\Pi / \Pi\end{array}$ & $\begin{array}{c}\text { Ознаки } \\
\text { психічного ускладнення }\end{array}$ & $\begin{array}{c}\text { Кількість осіб, } \\
\text { які вказали на } \\
\text { відповідну } \\
\text { ознаку } \\
\text { \% }\end{array}$ \\
\hline 1. & $\begin{array}{l}\text { Висловлювання жалю щодо власних вчинків, допущених у збудженому } \\
\text { стані в екстремальних умовах }\end{array}$ & 82 \\
\hline 2. & $\begin{array}{l}\text { Хвилювання при знайомстві } 3 \text { особою, до якої необхідно звернутися за } \\
\text { допомогою з професійною метою }\end{array}$ & 70 \\
\hline 3. & $\begin{array}{l}\text { Повільність у прийнятті негайних рішень в екстремальних (нештатних) } \\
\text { ситуаціях }\end{array}$ & 61 \\
\hline 4. & $\begin{array}{l}\text { Знервованість і часте роздратування під час } \\
\text { дій в складних умовах обстановки }\end{array}$ & 59 \\
\hline 5. & $\begin{array}{l}\text { Низький рівень реагування як результат негативного психічного стану в } \\
\text { нестандартних ситуаціях }\end{array}$ & 55 \\
\hline 6. & $\begin{array}{l}\text { Значний негативний вплив монотонності в роботі на психічний стан, що } \\
\text { призводить до шаблонності в процесі прийняття рішень }\end{array}$ & 51 \\
\hline 7. & $\begin{array}{l}\text { Виникнення труднощів у разі необхідності зміни одного виду діяльності на } \\
\text { інший під час виконання службових завдань }\end{array}$ & 25 \\
\hline 8. & Невпевненість у власних силах у ході виконання службових обов’язків & 25 \\
\hline 9. & $\begin{array}{l}\text { Розгубленість і невміння керувати своїм психічним станом у ході } \\
\text { виконання спеціальних завдань }\end{array}$ & 23 \\
\hline
\end{tabular}




\section{Питання психології}

Окрім цього був проведений аналіз взаємозв'язку психічної саморегуляції та успішності у навчанні 3 провідних навчальних дисциплін. Даний аналіз підтвердив наше припущення, що чим вище здатність до саморегуляції тим кращі результати у навчанні. Так, ми отримали результати (табл. 2), що вказують на зворотній зв'язок низької здатності до психічної саморегуляції слухачів, яка виражається в наявності психічних ускладнень, та їх успішністю 3 основних навчальних дисциплін.

Результати, що відображають взаємозв'язок психічних ускладнень слухачів з їх успішністю в навчальній діяльності

\begin{tabular}{|c|c|c|c|c|}
\hline \multirow[b]{2}{*}{$\begin{array}{l}\text { № } \\
\text { п/п }\end{array}$} & \multirow[b]{2}{*}{$\begin{array}{c}\text { Ознаки } \\
\text { психічного ускладнення }\end{array}$} & \multicolumn{3}{|c|}{$\begin{array}{c}\text { Кількість осіб, які вказали на відповідну } \\
\text { ознаку \% }\end{array}$} \\
\hline & & $\begin{array}{c}1 \text { група } \\
\text { високо } \\
\text { успішні } \\
\text { особи }\end{array}$ & $\begin{array}{c}2 \text { група } \\
\text { середньо } \\
\text { успішні } \\
\text { особи }\end{array}$ & $\begin{array}{c}3 \text { група } \\
\text { низько } \\
\text { успішні } \\
\text { особи }\end{array}$ \\
\hline 1. & $\begin{array}{l}\text { Висловлювання жалю щодо власних вчинків, } \\
\text { допущених у збудженому стані в } \\
\text { екстремальних умовах }\end{array}$ & 64 & 85 & 97 \\
\hline 2. & $\begin{array}{l}\text { Хвилювання при знайомстві з особою, до якої } \\
\text { необхідно звернутися за допомогою } 3 \\
\text { професійною метою }\end{array}$ & 50 & 66 & 94 \\
\hline 3. & $\begin{array}{l}\text { Повільність у прийнятті негайних рішень в } \\
\text { екстремальних (нештатних) ситуаціях }\end{array}$ & 45 & 54 & 84 \\
\hline 4. & $\begin{array}{l}\text { Знервованість і часте роздратування під час дій } \\
\text { в складних умовах обстановки }\end{array}$ & 40 & 52 & 85 \\
\hline 5. & $\begin{array}{l}\text { Низький рівень реагування як результат } \\
\text { негативного психічного стану в нестандартних } \\
\text { ситуаціях }\end{array}$ & 31 & 51 & 83 \\
\hline 6. & $\begin{array}{l}\text { Значний негативний вплив монотонності в } \\
\text { роботі на психічний стан, що призводить до } \\
\text { шаблонності в процесі прийняття рішень }\end{array}$ & 34 & 40 & 79 \\
\hline 7. & $\begin{array}{l}\text { Виникнення труднощів у разі необхідності } \\
\text { зміни одного виду діяльності на інший під час } \\
\text { виконання службових завдань }\end{array}$ & 11 & 24 & 40 \\
\hline 8. & $\begin{array}{lcccc}\text { Невпевненість у } \\
\text { виконання службосних силах } & \text { у } & \text { ході } \\
\end{array}$ & 5 & 25 & 45 \\
\hline 9. & $\begin{array}{l}\text { Розгубленість і невміння керувати своїм } \\
\text { психічним станом у ході виконання }\end{array}$ & 4 & 21 & 44 \\
\hline
\end{tabular}

Тут ми бачимо, що віднесені до низькоуспішної та середньоуспішної груп слухачі вказали на значно більшу кількість психічних ускладнень ніж високоуспішні. Це свідчить про безпосередній взаємозв'язок між успішністю та здатністю слухачів до психічної саморегуляції.

Таким чином, на основі результатів анонімного анкетування можна стверджувати, що проблемним питанням фахової підготовки майбутніх фахівців екстремальних видів діяльності МО України $\epsilon$ недостатня їх здатність до власної психічної саморегуляції.

Крім того, багаторічний педагогічний $\mathrm{i}$ практичний досвід науково-педагогічного складу ВВНЗ вказує, що фаховий рівень підготовленості, а отже і успішність слухачів при відпрацюванні завдань, пов'язаних із саморегуляцією своїх психічних станів, потребує вдосконалення. Особливо зазначена проблема загострюється в період перебування офіщерів-слухачів у нестандартних, стресових ситуаціях, коли необхідно приймати термінові i конкретні рішення (проведення навчань, польові виходи тощо). Так, було досліджено зміст відгуків керівників (начальників) структурних підрозділів, у яких проходять службу та обіймають відповідні посади випускники минулих років. За їх відгуками, випускники під час виконання своїх обов'язків мають проблеми щодо психічної та емоційної 


\section{Питання психології}

стійкості, а також впевненості у власних силах, що також є свідченням недостатньої здатності випускників до психічної саморегуляції.

3 метою з'ясування зазначеної проблеми та апробації методики діагностування здатності до психічної саморегуляції, був проведений другий етап нашого дослідження.

На другому етапі дослідження було проведено психологічне тестування, в якому взяли участь $100 \%$ слухачів денної форми навчання. Для діагностування впливу здатності до психічної саморегуляції офіцерів були апробовані такі методики:

1. Орієнтаційна анкета, яка використовувалася для 3'ясування окремих аспектів спрямованості слухачів, що впливають на ефективність їх навчальної діяльності, типу професійної спрямованості на рішення професійних (ділових) питань, взаємодію з іншими колегами або на себе.

2. Методика "Карта інтересів" - для діагностування професійних інтересів слухачів, що $є$ формою вияву їхніх потреб і складовою мотиваційної сфери майбутньої діяльності.

3. Тест структури інтелекту Амтхауера:

a) доповнення речення - для виявлення здатності до розвитку суджень, знань мови, самостійності і конкретно-практичного характеру мислення, почуття реальності;

б) вибір слів - для виявлення здатності до індуктивного практичного мислення, розуміння лексики, сприйняття змісту тексту і мови;

в) аналогії - для виявлення комбінаторних здатностей, рухливості мислення i здатності до перестановок, розуміння зв'язків між поняттями, ясності i послідовності мислення;

г) пошук спільності - для виявлення мовно-логічного мислення, здатності до абстрагування, вміння висловлювати судження;

д) арифметичні задачі - для виявлення практичних здатностей до дедуктивного математичного мислення;

е) числові ряди - для виявлення теоретичних рахункових здатностей, індуктивного числового мислення, рухливості мислення i здатності до перестановок, передумов до математичної обдарованості;

є) вибір фігури - для виявлення здатностей до уявлення, наочно-образного, комбінаторного мислення, образноконструктивних компонентів мислення;

ж) завдання з кубиками - для виявлення здатностей до просторового уявлення, аналітичних здатностей, технікоконструктивних компонентів мислення;

3) завдання на пригадування - для виявлення здатностей до довгострокового запам'ятовування та актуалізації отриманої інформації.

4. Опитувальник для оцінювання вольового самоконтролю - для визначення індивідуального рівня розвиненості вольової саморегуляції.

5. Оцінка тенденцій поведінки в групі за В. Стефансоном (Q-сортування) - для визначення шести основних тенденцій поведінки майбутніх співробітників спеціальних підрозділів у реальній групі: залежність - незалежність, товариськість нетовариськість, прийняття боротьби уникнення боротьби.

6. Модифікований варіант методики САН за Н. Курганським (5-факторна модель) - для оцінювання рівня ситуативної (реактивної) тривожності.

Кожна 3 описаних методик використовувалася для діагностування здатності до психічної саморегуляції майбутніх фахівців екстремальних видів діяльності під час професійного психологічного відбору.

3 метою статистичної перевірки можливості використання зазначених психодіагностичних методик за відповідними критеріями оцінювання психічної саморегуляції був проведений кореляційний аналіз результатів, отриманих слухачами в I-IV семестрах.

Під час кореляційного аналізу (аналіз проводився на основі пакету статистичних програм SPSS 15.0) визначено кореляційний зв'язок між успішністю зі спеціальних дисциплін (практичної підготовки) з такими показниками психологічних тестів, які характеризують рівень психічної саморегуляції слухачів.

Між шкалою залежність-незалежність (показники даного критерію виявляють вміння майбутніх випускників регулювати власну поведінку) та середнім балом успішності; коефіцієнт кореляції за Спірменом складає $\mathrm{r}=0,380$ (Де * - рівень статистичної значущості $<0,05$. 


\section{Питання психології}

Достовірність зв'язку була перевірена за таблицею критичних значень вибіркового коефіцієнту кореляції рангів (за В.Ю. Урбахом, 1964). (Q-сортування).

Отримані на основі цієї ж методики дані вказують на кореляційний зв'язок між показниками успішності та здатністю відстоювати свої інтереси $\mathrm{r}=0,475^{*}$, взаємодіяти 3 колегами в процесі спілкування, в конфліктних ситуаціях складає $\mathrm{r}=0,463 *$ (поведінково-діяльнісний критерій) .

У ході дослідження також встановлено і кореляційний зв'язок між успішністю слухачів та показниками інтелекту, отриманих на основі шкал тесту структури інтелекту Амтхауера (когнітивний критерій). Так, між шкалою здатність до абстрагування, уміння висловлювати судження та мовно-логічне мислення та середнім балом успішності складає $\mathrm{r}=0,350 *$, між шкалою здатність до комбінаторного, числового, образно-конструктивного мислення і середнім балом успішності 3 основних дисциплін і практичної польової підготовки - $\mathrm{r}=0,390^{*}$, між шкалою здатність до аналітичних здібностей техніко-конструктивних компонентів мислення та середнім балом успішності складає $\mathrm{r}=0,368^{*}$.

Одним з основних питань дослідження було визначення індивідуального рівня розвиненості у майбутніх МВУМВ рівня вольової саморегуляції. В ході статистичного аналізу нами був виявлений кореляційний зв'язок між успішністю та отриманим результатом, які характеризуються емоційно-вольовим критерієм. Зокрема, між шкалою цілеспрямованість, самостійність, самовладання (Опитувальник для оцінки вольового самоконтролю) та середнім балом успішності складає $\mathrm{r}=0,370 *$.

Під час статистичного аналізу визначено кореляційний зв'язок між середнім балом успішності і показниками за шкалою активація та інтерес, що складає $\mathrm{r}=0,347^{*}$ (модифікований варіант методики САН за Н. Курганським, психологічними показниками цієї методики $\epsilon$ активація, інтерес, емоційний тонус, напруженість i комфортність який використовувався нами для визначення суб'єктного критерію).

Таким чином, результати статистичного аналізу щодо визначення кореляційного зв'язку успішності слухачів 3 результатами психологічного тестування підтвердили можливість використання визначених нами методик для діагностування рівня психічної саморегуляції фахівців екстремальних професій.

Висновок. Нами були апробовані методики для діагностування здатності до психічної саморегуляції офіцерів оперативно-тактичного рівня підготовки на основі поведінково-діяльнісного, когнітивного, емоційно-вольового та суб'єктного критеріїв. З'ясували, що існує зворотній зв'язок між здатністю до психічної саморегуляції слухачів та їх успішністю 3 основних навчальних дисциплін.

Під час подальших наукових пошуків плануємо розробити та експериментально перевірити тренінг щодо розвитку здатності до саморегуляції майбутніх фахівців екстремальних видів діяльності в процесі їх практичної підготовки.

\section{Список використаних джерел}

1. Барко B.I. Теоретико-психологічні засади управління персоналом органів внутрішніх справ: дис. ... д-ра психол. наук: спец. 19.00.06. Київ, 2004. 401 с.

2. Китаев-Смык Л.А. Психология стресса. Москва: Наука. 1983. 368 с.

3. Максименко С.Д. Общая психология. Киев: Ваклер. 2004. 528 с.

4. Наказ Генерального штабу Збройних Сил України від 04 грудня 2014 року № 317. Киев, 2014. 8 с.

5. Небылицын В.Д. Психофизиологическое исследование индивидуальных различий. Москва: Наука. 1976. 336 с.

6. Стасюк В.В. Формування емоційної стійкості у воїнів-десантників в умовах сучасного бою: автореф. дис. на здобуття наук. ступеня канд. психол. наук: спец. 20.02.02 Військова педагогіка та психологія. В.В. Стасюк. Киев, 1999. 15 с.

7. Толочек В.А. Современная психология труда. Учеб. пособие для вузов по направлениям и специальностям психологии. С. - Петербург, 2005. 478 с. 


\section{Питання психології}

\section{References}

1. Barko V.I. Teoretyko-psykholohichni zasady upravlinnya personalom orhaniv vnutrishnikh sprav: dys. d-ra psykhol. nauk: spets. 19.00.06. Kyyiv, 2004. $401 \mathrm{~s}$

2. Kitaev-Smyik L.A. Psihologiya stressa. Moskva: Nauka. 1983. 368 s.

3. Maksimenko S.D. Obschaya psihologiya. Kiev: Vakler. 2004. $528 \mathrm{~s}$.

4. Nakaz Heneral'noho shtabu Zbroynykh Syl Ukrayiny vid 04 hrudnya 2014 roku \# 317. Kyev, 2014. 8 s. $336 \mathrm{~s}$

5. Nebyilitsyin V.D. Psihofiziologicheskoe issledovanie individualnyih razlichiy. Moskva: Nauka. 1976.

6. Stasyuk V.V. Formuvannya emotsiynoyi stiykosti u voyiniv-desantnykiv v umovakh suchasnoho boyu: avtoref. dys. na zdobuttya nauk. stupenya kand. psykhol. nauk: spets. 20.02.02 Viys'kova pedahohika ta psykholohiya. V.V. Stasyuk. Kyev, 1999. $15 \mathrm{~s}$.

7. Tolochek V.A. Sovremennaya psihologiya truda. Ucheb. posobie dlya vuzov po napravleniyam i spetsialnostyam psihologii. S. - Peterburg, 2005. $478 \mathrm{~s}$.

\section{SUMMARY}

Furs O. I., deputy chief of the faculty for personnel

RESULTS OF WOULD-BE EXPERTS' IN EXTREME ACTIVITY SELF-REGULATION ABILITY TO INFLUENCE THE SUCCESS OF PROFESSIONAL TRAINING

The article defines one of the leading psychological problems - ability of the experts in extreme activity for self-regulation. It proves necessity to conduct experimental verification of it among the military servicemen in combat areas.

It regards the researchers' views at understanding the ability of the special units representatives to regulate their own psychological states in extreme situations.

It shows the results of using testing techniques to establish ability to psychological self-regulation of the operational-tactical level training.

It also demonstrates statistical link between performance on special subjects and practical training with the test results, showing the level of psychological self-regulation of the officer-students as woul-be experts in extreme activities.

Keywords: ability to self-regulate, experts in extreme activities, progress, professional training, correlation analysis, statistical connection. 